\title{
ANALISIS METODE SEROLOGI WIDAL LAPANGAN, WIDAL PEMBANDING, DAN KULTUR PADA PENDERITA SUSPEK DEMAM TIFOID DI SULAWESI SELATAN
}

\author{
Syamsu Rijal \\ Fakultas Kedokteran Universitas Muslim Indonesia \\ Email : rijalrat@yahoo.com.
}

\begin{abstract}
The aim of the study was to discover the difference of field widal and comparative widal in detecting Salmonella typhi in typhoid suspect patient, sensitivity, specificity, positive and negative prediction scores of Widal and to culture. The study was conducted at the Biomolecular and Immunology Laboratory of the faculty of Medicine Hasanuddin University. The number of samples was 40 typhoid suspect patiens colleted from examination of field Widal at public health centers and hospitals in south Sulawesi. The serum samples of the patient were reexamined by using Widal comparative methods, and culture examination was done to blood sample. The results of the study indicate that comparative widal sensitivity $70 \%$, spesificity $26 \%$, positive predictive score $24,1 \%$, negative predictive score $16,7 \%$, and filed Widal sensitivity $30 \%$, specificity $30 \%$, positive predictive score $16,7 \%$, and negative predictive score $68,2 \%$. The comparative Widal has higher sensitivity than field Widal.
\end{abstract}

Key Words: Field Widal, Comparative Widal, Culture, Typhoid Suspect.

\section{PENDAHULUAN}

Demam Tifoid (DT) merupakan penyakit infeksi akut dan bersifat endemis yang disebabkan oleh Salmonella typhi (S. typhi) yang termasuk bakteri gram negatif berbentuk basil dan bersifat patogen intraselular pada manusia (Kwenang, 2007). Masa inkubasi DT umumnya 12 minggu bahkan dapat lebih panjang sampai 30 hari, dan setelah itu gejala pada umumnya menyerupai infeksi akut, yaitu demam, nyeri kepala, pusing, nyeri otot, anoreksia, mual, muntah, batuk dan konstipasi (Jawetz., dkk., 1995 ; Sjaifoellah, 1996; Muliawan, 1999).Penyakit ini juga merupakan masalah kesehatan masyarakat yang penting karena penyebarannya berkaitan erat dengan urbanisasi, kepadatan penduduk, kesehatan lingkungan, sumber air dan sanitasi yang buruk serta standar higiene industri pengolahan makanan yang masih rendah. Penyakit ini mudah berpindah dari satu orang ke orang lain misalnya orang yang tidak mencuci tangan setelah dari toilet dan 
Analisis Metode Serologi Widal Lapangan, Widal Pembanding, Dan Kultur Pada Penderita Suspek Demam Tifoid Di Sulawesi Selatan

dapat menyebarkan ke orang lain, (Dewitt, 2002; Prasetyo, 2003). Penyebaran DT terjadi melalui fecal-oral melalui makanan dan minuman yang terkontaminasi oleh bakteri Salmonella typhi (Ball.A.P,1992).

Kasus DT di Indonesia, dilaporkan sebagai penyakit endemis dimana 95\% merupakan kasus rawat jalan sehingga insidens yang sebenarnya adalah 15 - 25 kali lebih besar dari laporan rawat inap di rumah sakit. Di Indonesia kasus ini tersebar secara merata di seluruh propinsi dengan insidens di daerah pedesaan 358/100.000 penduduk/ tahun dan di daerah perkotaan 760/100.000 penduduk/tahun atau sekitar 600.000 dan 1.5 juta kasus per tahun. Umur penderita DT di Indonesia dilaporkan antara 3-19 tahun sebanyak 91\% kasus (Prasetyo, 2003).

Di Sulawesi Selatan, penderita DT terjadi peningkatan dari tahun 1990 terdapat 8.528 penderita DT menjadi 24.405 penderita DT pada tahun 1995 , sedangkan angka kematian meningkat dari $1,80 \%$ menjadi $4,59 \%$ (Windarti, 1998). Jumlah penderita DT pada tahun 2005 sebesar 2210 orang, dan berada pada urutan ke-5 dari 20 penyakit terbanyak penderita rawat inap di sejumlah rumah sakit di
Makasar, sehingga merupakan masalah kesehatan masyarakat (Karim, 2005). Berdasarkan laporan tahun 2005 jumlah penderita sebanyak 16.478 dengan kematian sebanyak 6 orang,dan tahun 2006 dari 23 kabupaten/kota di Sulawesi Selatan jumlah penderita DT sebanyak 16.909 dengan kematian sebanyak 11 orang. Hal ini menunjukkan bahwa terjadi peningkatan jumlah kasus dan kematian. Jumlah penderita DT tertinggi di temukan di kabupaten Gowa, kota Makasar, kabupaten Enrekang dan kota Parepare. Insidens penyakit DT menurut waktu terlihat ada kecenderungan peningkatan kasus pada bulan Juli dan mulai meningkat di bulan Agustus, dimana pada bulan tersebut adalah musim kemarau. (Manguluang, 2006).

Kecenderungan meningkatnya angka kejadian DT di Indonesia terjadi karena banyak faktor, antara lain urbanisasi, sanitasi yang buruk, karier yang tidak terdeteksi, dan keterlambatan diagnosis, serta metode pemeriksaan secara fisis dan laboratrium yang dilakukan. Dengan melihat data tersebut di atas, baik insidens penyakit DT yang makin meningkat maupun angka kematian yang disebabkannya, maka diagnosis dini DT perlu ditegakkan, olehnya itu 
Analisis Metode Serologi Widal Lapangan, Widal Pembanding, Dan Kultur Pada Penderita Suspek Demam Tifoid Di Sulawesi Selatan

ketepatan dalam membuat diagnosis berdasarkan pemeriksaan fisis dan serologi yang sampai saat ini masih dikerjakan hampir pada semua pasien yang dirawat dengan demam di rumah sakit, yaitu uji Widal, perlu ditinjau kembali (Muliawan,1999).

Diagnosis DT sulit untuk dapat ditegakkan hanya atas dasar gejala klinis saja, sebab gambaran klinis penyakit ini amat bervariasi dan umumnya tidak khas untuk DT. Dengan demikian peranan laboratorium dalam membantu menegakkan diagnosis amat penting (Muliawan,1999 ; Sabir, dkk., 2003).

Pemeriksaan laboratorium untuk menegakkan diagnosis DT yaitu dengan metode klasik (kultur), serologi, serta menggunakan teknik molekuler. Setiap metode yang digunakan memiliki kekurangan dan kelebihan masing-masing. Diagnosis DT dengan metode klasik yaitu dengan mengkultur Salmonella typhi dari sampel darah, tinja maupun urin. Walaupun kultur darah dipakai sebagai gold standard, namun kultur darah memiliki kekurangan antara lain dalam hal sensitivitas, dan lamanya waktu yang digunakan untuk kultur. Kultur darah memiliki batas sensitifitas yang pada umumnya disebabkan oleh penggunaan antibiotik oleh pasien sebelum pemeriksaan, lama demam, dan kecilnya volume darah yang digunakan untuk kultur, atau bakteri $S$. typhi dalam sampel berada dalam kondisi viable noncultivable, artinya tetap hidup dalam sampel yang diperoleh tetapi tidak dapat ditumbuhkan atau dikulturkan (Hatta, dkk., 2002).

Pemeriksaan serologi yang masih sering dilakukan yaitu uji Widal, merupakan metode serologi baku yang digunakan sejak tahun 1896. Uji Widal dapat dilakukan dengan menggunakan metode tabung atau dengan metode slide. Uji Widal metode slide dapat dikerjakan lebih cepat dibandingkan dengan metode tabung, tetapi ketepatan dan spesifitas metode tabung lebih baik dari metode slide (Mokoginta, dkk., 2002). Penelitian yang dilakukan Handojo (2004) nilai sensitivitas pada uji Widal metode Slide $82,93 \%$, spesifitas $64,28 \%$, dengan menggunakan antigen lokal produksi Mekar Jaya Diagnostika (SAT-MJD). Metode Widal juga memiliki keterbatasan dengan adanya hasil positif palsu dan negatif palsu, selain itu memiliki spesifitas yang agak rendah (Sabir, dkk., 2003).

\section{METODOLOGI PENELITIAN}

Penelitian ini bersifat eksperimental, dengan mendeteksi 
Analisis Metode Serologi Widal Lapangan, Widal Pembanding, Dan Kultur Pada Penderita Suspek Demam Tifoid Di Sulawesi Selatan

kuman Salmonella typhi dalam darah penderita suspek DT sehingga didapatkan sensitifitas dan spesifitas dari masing-masing pengujian yang bertujuan menegakkan diagnosa DT. Populasi dalam penelitian ini adalah seluruh sampel darah dari penderita suspek DT yang diambil dari Puskesmas dan Rumah Sakit di Wilayah Sulawesi Selatan.

Sampel darah sebanyak $3 \mathrm{ml}$ dari penderita suspek DT sebanyak 40 sampel. Adapun Kriteria Sampel sebagai berikut; suspek DT adalah penderita yang mempunyai suhu di atas $>37,2{ }^{\circ} \mathrm{C}$ selama lebih dari 3 hari dan telah melalui pemeriksaan dokter dan dinyatakan suspek DT. Kriteria penolakan sampel; penderita demam yang disebabkan oleh kuman infeksi lainnya.Variabel penelitian; hasil uji widal lapangan dan widal pembanding, serta hasil kultur.

\section{HASIL PENELITIAN}

Deteksi S. typhi pada 40 sampel darah suspek DT dilakukan dengan menggunakan metode kultur darah, Widal pembanding dan lapangan, serta dridot pada tabel 1 .

Tabel 1. Frekuensi diagnosis akhir kultur darah berdasarkan lama demam

\begin{tabular}{ccccccc}
\hline & \multicolumn{3}{c}{ Kultur Darah (\%) } & \multicolumn{2}{c}{ Total } \\
\cline { 2 - 6 } Lama Demam (Hari) & \multicolumn{2}{c}{ Positif } & \multicolumn{2}{c}{ Negatif } & \multirow{2}{*}{$\mathbf{n}$} & $\%$ \\
\cline { 2 - 6 } & $\mathbf{n}$ & $\%$ & $\mathbf{n}$ & $\%$ & & \\
\hline$<7$ & 8 & 20 & 15 & 37,5 & 23 & 57,5 \\
$\geq 7$ & 2 & 5 & 15 & 37,5 & 17 & 42,5 \\
\hline TOTAL & 10 & 25 & 30 & 75 & 40 & 100 \\
\hline
\end{tabular}

Tabel 2. Frekuensi diagnosis akhir metode Widal Lapangan berdasarkan lama demam

\begin{tabular}{cccccccc}
\hline \multirow{2}{*}{ Lama Demam (Hari) } & \multicolumn{3}{c}{ Widal Lapangan (\%) } & \multicolumn{2}{c}{ Total } \\
\cline { 2 - 6 } & \multicolumn{3}{c}{ Positif } & \multicolumn{2}{c}{ Negatif } & \multirow{2}{*}{$\mathbf{n}$} & $\%$ \\
\cline { 2 - 7 } & $\mathbf{n}$ & $\%$ & $\mathbf{n}$ & $\%$ & & \\
\hline$<7$ & 9 & 22,5 & 14 & 35 & 23 & 57,5 \\
$\geq 7$ & 9 & 22,5 & 8 & 20 & 17 & 42,5 \\
\hline TOTAL & 18 & 45 & 22 & 55 & 40 & 100 \\
\hline
\end{tabular}

Tabel 3. Frekuensi diagnosis akhir metode Widal Pembanding berdasarkan lama demam

\begin{tabular}{cccccccc}
\hline \multirow{2}{*}{ Lama Demam (Hari) } & \multicolumn{3}{c}{ Widal pembanding(\%) } & \multicolumn{2}{c}{ Total } \\
\cline { 2 - 6 } & \multicolumn{2}{c}{ Positif } & \multicolumn{2}{c}{ Negatif } & \multirow{2}{*}{$\mathbf{n}$} & $\%$ \\
\cline { 2 - 6 } & $\mathbf{n}$ & $\%$ & $\mathbf{n}$ & $\%$ & & \\
\hline$<7$ & 16 & 40 & 7 & 17,52 & 23 & 57,5 \\
$\geq 7$ & 13 & 32,5 & 4 & 10 & 17 & 42,5 \\
\hline TOTAL & 29 & 45 & 11 & 27,5 & 40 & 100 \\
\hline
\end{tabular}


Analisis Metode Serologi Widal Lapangan, Widal Pembanding, Dan Kultur Pada Penderita Suspek Demam Tifoid Di Sulawesi Selatan

Tabel 4. Tabulasi silang metode kultur darah dan Widal lapangan untuk diagnosis Demam Tifoid

\begin{tabular}{|c|c|c|c|c|c|c|c|}
\hline & \multicolumn{4}{|c|}{ Kultur } & \multirow{2}{*}{\multicolumn{2}{|c|}{ Total }} \\
\hline & & & & & & & \\
\hline \multirow{3}{*}{$\begin{array}{c}\text { Widal } \\
\text { Lapangan }\end{array}$} & & $n$ & $\%$ & $\mathbf{n}$ & $\%$ & $\mathbf{n}$ & $\%$ \\
\hline & Positif & 3 & 7,5 & 15 & 37,5 & 18 & 45 \\
\hline & Negatif & 7 & 17,5 & 15 & 37,5 & 22 & 55 \\
\hline \multicolumn{2}{|c|}{ Total } & 10 & 25 & 30 & 75 & 40 & 100 \\
\hline
\end{tabular}

Tabel 5. Tabulasi silang metode kultur darah dan widal pembanding untuk diagnosis demam tifoid

\begin{tabular}{cccccccc}
\hline & \multicolumn{4}{c}{ Kultur } & \multicolumn{2}{c}{ Total } \\
\cline { 2 - 8 } & \multicolumn{2}{c}{ Positif } & \multicolumn{2}{c}{ Negatif } & \multicolumn{2}{c}{} \\
\hline \multirow{2}{*}{$\begin{array}{c}\text { Widal } \\
\text { Pembanding }\end{array}$} & $\mathbf{n}$ & $\%$ & $\mathbf{n}$ & $\%$ & $\mathbf{n}$ & $\%$ \\
\cline { 2 - 8 } & Positif & 7 & 17,5 & 22 & 55 & 29 & 72,5 \\
\cline { 2 - 8 } & Negatif & 3 & 7,5 & 8 & 20 & 11 & 27,5 \\
\hline \multicolumn{2}{c}{ Total } & 10 & 25 & 30 & 75 & 40 & 100 \\
\hline
\end{tabular}

Tabel 6. Nilai Sensitivitas, Spesifitas, Nilai Prediksi Positif dan Nilai Prediksi Negatif dari widal pembanding, dan widal lapangan terhadap kultur

\begin{tabular}{ccccc}
\hline Metode & $\begin{array}{c}\text { Sensitivitas } \\
(\%)\end{array}$ & $\begin{array}{c}\text { Spesifitas } \\
(\%)\end{array}$ & $\begin{array}{c}\text { Nilai Prediksi } \\
\text { Positif (\%) }\end{array}$ & $\begin{array}{c}\text { Nilai Prediksi } \\
\text { Negatif (\%) }\end{array}$ \\
\hline Widal Lapangan & 30 & 50 & 16.7 & 68.2 \\
Widal Pembanding & 70 & 26.7 & 24.1 & 72.8 \\
\hline
\end{tabular}

\section{PEMBAHASAN}

Pada tabel 1. menunjukkan bahwa terdapat $8(20 \%)$ penderita positif yang demam kurang dari tujuh hari, $2(5 \%)$ penderita positif yang demam lebih dari tujuh hari. Jumlah seluruh penderita $10(25 \%)$ positif DT, dan 30 (75\%) pasien negatif.

Pada tabel 2. menunjukkan bahwa dari 40 sampel penderita suspek DT berdasarkan lama demam dengan menggunakan tes Widal lapangan didapatkan hasil 9 (22,5\%) penderita yang demam kurang dari tujuh hari, $9(52,9)$ penderita yang demam lebih dari tujuh hari. Total penderita 18 (45\%) yang positif. Pada gambar 1. Uji Widal lapangan diperlihatkan metode aglutinasi cara slide mulai titer 1/80 sampai 1/320, hanya saja pada metode tersebut perbandingan antara serum darah penderita suspek DT dengan kit Widal tidak jelas. Demikian juga pembacaan hasil uji Widal pada masing-masing titer juga tidak akurat. Interpretasi pada titer 1/80 dinyatakan dengan aglutinasi yang minimal, titer 1/160 dinyatakan dengan aglutinasi sedang, dan titer 1/320 dinyatakan dengan 
Analisis Metode Serologi Widal Lapangan, Widal Pembanding, Dan Kultur Pada Penderita Suspek Demam Tifoid Di Sulawesi Selatan

aglutinasi pada semua bagian serum tadi, sementara untuk titer 1/640 tidak bisa dibaca.

Pada tabel 3 menunjukkan dari 40 sampel penderita DT berdasarkan lama demam dengan menggunakan Widal pembanding didapatkan hasil 16 (40\%) penderita DT yang demam kurang dari tujuh hari, $13(32,5)$ penderita DT yang demam lebih dari tujuh hari, dari 29 (72,5\%) positif, dan hanya $11(27.5 \%)$ negatif.

Tabel 4 menunjukan bahwa 3 (7,5\%) penderita DT positif kultur dan widal lapangan. Uji Fisher's Exact Test diperoleh $p=0,233(p>0,05)$.

Tabel 5 menunjukan bahwa $7(17,5 \%)$ pasien positif kultur darah dan widal pembanding. Uji Fisher's Exact Test diperoleh nilai $\mathrm{p}=0,589$ ( $p>0,05)$. Setelah melakukan masingmasing pengujian, yaitu uji kultur darah, Widal pembanding dan Widal lapangan, maka diperoleh sensivitas, spesifitas, Nilai Prediksi Positif (NPP), dan Nilai Prediksi Negatif (NPN) dapat dilihat pada tabel 6 . Pada tabel 6 menunjukkan nilai sensitifitas, spesifitas, nilai prediksi positif, nilai prediksi negatif dari masing-masing metode widal lapangan, pembanding,.secara berturut-turut $30 \%, \quad 50 \%$, 16.7\%, 68.2\%, 70\%, $26.7 \%, 24.1 \%, 72.8 \%$.
Berdasarkan hasil diagnosis dari penderita suspek DT dengan kultur darah (tabel 1), bahwa untuk rentang waktu demam kurang dari 7 hari diperoleh hasil yang positif sebanyak 8 (20\%) sampel. Hal ini berarti hasil positif didapatkan pada minggu pertama berlangsungnya penyakit. Kultur positif tersebut disebabkan pada minggu-minggu pertama merupakan fase bakterikimia dan septikimia yang berat, di mana basil-basil tifoid dalam darah jumlahnya banyak. Sedangkan pada rentang waktu $\geq 7$ hari, diperoleh hasil positif yang lebih sedikit 2 (5\%). Ini dapat disebabkan semakin berkurangnya jumlah basil-basil tifoid S. typhi di dalam darah, seiring dengan terjadinya peningkatan antibodi yang biasanya dimulai pada hari ke-7 demam (Baratawidjaja. 2002).

Kultur memiliki keterbatasan sensitivitas, yang diperkirakan bisa mencapai 65,3\% (Hatta, 2002). Sensitivitas dari darah yang lebih rendah dapat disebabkan oleh berbagai faktor termasuk frekuensi penggunaan antibiotik yang tinggi, rendahnya dosis infektif dan relatif, dan sedikitnya volume darah yang digunakan pada saat pemeriksaan (Sabir, 2003). 
Analisis Metode Serologi Widal Lapangan, Widal Pembanding, Dan Kultur Pada Penderita Suspek Demam Tifoid Di Sulawesi Selatan

Menurut Song, kultur darah hanya dapat mendeteksi $45-70 \%$ pada pasien DT tergantung pada jumlah sampel darah, tingkatan bakterimia pada $S$. typhi, dan tipe medium kultur yang digunakan.

Hasil uji statistik Chi square Fisher's Exact Test untuk melihat pengaruh lama demam terhadap hasil kultur darah diperoleh nilai kemaknaan $p=(p>0,145)$. Dapat disimpulkan bahwa lama demam tidak ada hubungan bermakna terhadap hasil kultur darah .

Antara Widal pembanding dan Widal lapangan terhadap kultur ditemukan penderita DT masingmasing $3(7,5 \%)$ dengan pemeriksaan Widal lapangan yang positif kultur, dan 7 (17,5\%) dengan pemeriksaan Widal Pembanding yang positif kultur. Pada Widal lapangan digunakan metode slide, sementara pada Widal pembanding digunakan metode tabung dengan melakukan dilusi (pengenceran).

Pengamatan yang dilakukan terhadap Widal lapangan bahwa baik pada pusat pelayanan kesehatan masyarakat atau rumah sakit, semua menggunakan metode slide. Hanya saja dalam prakteknya prosedur pemeriksaan tidak mengikuti standar yang ditetapkan (Handojo I, 2004).
Perbandingan konsentrasi antara serum, buffer saline, antigen Widal, tidak diperhatikan, interpretasi hasil dibaca terlalu lama, standar pengenceran pada konsentrasi ; $1 / 80$, 1/160. 1/320, 1/640, 1/1280 tidak jelas. Hasil interpretasi lebih cepat merupakan pertimbangan yang penting, sehingga banyak digunakan.

Uji Widal pembanding dengan menggunakan metode tabung merupakan metode konvensional, dengan tingkat ketelitian lebih baik dari metode slide (Wardhani, 2004). Metode tabung juga memilki kekurangan yakni membutuhkan waktu inkubasi semalam, dan peralatan yang digunakan cukup banyak, sehingga dianggap kurang praktis.

Pada Fisher's Exact Test menunjukkan tidak ada perbedaan bermakna antara Widal pembanding dan Widal lapangan terhadap kultur. Hal bisa disebabkan karena terbatasnya jumlah sampel dalam penelitian ini.

Berdasarkan hasil pada tabel 3 , pada kasus dengan lama demam $<7$ hari hasil yang positif $23(57.5 \%)$, dan hasil positif pada kasus lama demam $\geq 7$ hari sebanyak 17 (42,5\%). Hal ini dapat dijelaskan bahwa semakin lama terjadinya demam, 
Analisis Metode Serologi Widal Lapangan, Widal Pembanding, Dan Kultur Pada Penderita Suspek Demam Tifoid Di Sulawesi Selatan

maka antibodi yang terbentuk akan semakin tinggi dan jumlah bakteri akan semakin berkurang, karena antibodi semakin aktif untuk memfagot bakteri. Menurut Baratawijaya 1996, bahwa kadar IgM mencapai puncaknya selama 7 - 14 hari, dan setelah 14 hari mulai menurun tetapi tetap berada dalam darah sampai 30 hari. Pada kasus DT menunjukkan bahwa lama demam antara $3-15$ hari sehingga titer IgM masih tinggi .

Hasil tabulasi pada tabel 6 menunjukkan nilai sensitivitas tertinggi terhadap kultur pada widal lapangan terhadap kultur sensitivitas 30\%, spesifitas 50\%, (NPP) 16.7\%, (NPN) $68.2 \%$. Metode Widal pembanding sensitivitas $70 \%$, spesifitas $26.7 \%$, (NPP) 24.1\%, (NPN) $72.8 \%$.

Uji widal dalam menegakan diagnosa DT harus hati-hati karena beberapa faktor dapat mempengaruhi hasil pemeriksaannya, antara lain gizi, penggunaan antibiotik yang mendahului, daerah endemis, status imunologis, vaksinasi, penggunaan obat imunosupresan, reaksi silang, serta teknik pemeriksaan (Wardhani $\mathrm{P}$, 2005). Hal ini terlihat jelas pada saat melakukan pengamatan dilapangan pada penggunaan uji Widal metode slide. Menjadi perhatian bahwa seharusnya penggunakan uji Widal metode slide harus memperhatikan rasio serum, fosfat buffer saline, antigen, dalam penentuan titer (Handojo I, 2004).

Uji Widal pembanding cara tabung dengan melakukan dilusi mudah tetapi membutuhkan waktu yang lama. Uji Widal lapangan yang banyak digunakan adalah metode slide, meskipun cepat tetapi sensitivitas sangat rendah.

\section{KESIMPULAN}

Berdasarkan hasil penelitian ini dapat disimpulkan bahwa :

1. Uji Widal pembanding dapat mendeteksi kasus DT lebih baik dibandingkan dengan Uji Widal lapangan.

2. Uji Widal Pembanding mempunyai sensitivitas $70 \%$, spesifitas $26.7 \%$, NPP24.1\%, NPN 72,8\%,

3. Uji Widal lapangan adalah : mempunyai sensitivitas $30 \%$, spesifitas $50 \%$, NPP $16.7 \%$, NPN $68.2 \%$.

\section{DAFTAR PUSTAKA}

Alimudai. 2000. Nilai Diagnostik Uji Widal Tunggal penderita Demam tifoid. Karya akhir. FKUNHAS.

Ashkenazi S., Cleary T.G. Infeksi Salmonella. Dalam : Nelson W.E., Bechrman R.E., Kliegman R., Arvin.A.M. 2000. Nelson texbook of pediactrics, Edisi 15. EGC. Jakarta. 
Analisis Metode Serologi Widal Lapangan, Widal Pembanding, Dan Kultur Pada Penderita Suspek Demam Tifoid Di Sulawesi Selatan

Anonymous. 2006. Typhoid Fever. (Online). (http : :// nhs.direct.nhs.uk/ articles/ article.aspx? articled 380\&Sectionid.12570 14k. diakses 20 Oktober 2008).

Anggraini R., handoyo I., Aryati. 2004. Dot-ElA typhoid tes using OMP Salmonella typhi local Phage type antigen to support the siagnosis of typhoid Fever. Folia Medica Indonesia.

Anonymous. 1993. Buku Ajar Mikrobiologi Kedokteran. Staf Pengajar Fakultas Kedokteran Universitas Indonesia. Binarupa Aksara. Jakarta.

Abhyankar. 2002. (Online) Antigenic Structure of Salmonellae. http://www.geocities.com/avinas $\mathrm{h} /$ antigen.html. diakses 18 Juni 2009).

Abdoel, T.H, Pastoor, R, Smits, H.L. and Hatta, M, 2007. Laboratory Evaluation of a Simple and Rapid Latex Agglutination Assay for The Serodiagnosis of Typhoid Fever. Transcription of The Royal Society of Tropical Medicine and Hygiene, vol.101, $1032-1038$.

$\mathrm{h}$

Burrows, W. 1993. Text Book of Mikrobiology. $20^{\text {th }}$ edition. W.B. Saunders Company. Mexico.

Baratawidjaya, KG. 2006. Imunologi Dasar Edisi VII. Fakultas Kedokteran Universitas Indonesia. Jakarta.

Bahrun U. 2009. Diagnosis Demam Tifoid dengan anti-Salmonella typhi IgM. Disampaikan dalam symposium Prodia.
Ball, A.P., Gray, J.A. 1992. Penyakit Infeksi (Atlas Bantu). Hipokrates, Jakarta.

Cappucino, JG, Shierman, N. 1992. Microbiology a Laboratory Manual. $3^{\text {th }}$ Edition. Company Publishing Company. New York.

Campbell, 2004. Biologi. Penerbit Erlangga, Jakarta.

Cleary TG. Salmonella.,2000., Dalam : Behrman RE, Kliegman RM, Jenson HB, Eds. Nelson.Textbook of Pediatrics, edisi 16. Philadelphia : WB Saunders. :842-8.

Djauzi, S. 2005. Mencegah Demam Tifoid. (Online). (http://www.kompas. com/kesehatan/news/0503/27/0 90454.htm, diakses 11 Agustus 2008)

Depatemen Kesehatan RI. 1997. Survei Kesehatan Rumah Tangga. Badan Penelitian dan Pengembangan Kesehatan, Jakarta.

Davis, BD, et al. 1990. Microbiology $3^{\text {th }}$ edition. Harper and Row International Edition.

Darmowandowo W., 2002 Demam Tifoid. Dalam : Soedarmo SS, Garna H, Hadinegoro SR,Eds. Buku Ajar Ilmu Kesehatan Anak : Infeksi \& Penyakit Tropis, edisi 1. Jakarta : BP.FKUI., hal :36775.

Easmon, Charlie. 2002. Typhoid Fever and Paratyphoid Fever. http://www.netdoctor.co.uk/trave l/diseases/typhoid.htm. 
Analisis Metode Serologi Widal Lapangan, Widal Pembanding, Dan Kultur Pada Penderita Suspek Demam Tifoid Di Sulawesi Selatan

Ferri, F. 2004. Clinical Advisor Instant Diagnosis and Treatment, Mosby, USA: 885.

Garrity, G. 2000. Bergey's Manual of Systematic Bacteriology, $2^{\text {th }}$ edition.

http://www.cme.msu.edu/Berge ys/outline.prn.pdf.

Gupte, S. 1990. Mikrobiologi Dasar. Alih bahasa Julius ES. Binarupa Aksara. Edisi III. Jakarta.

Gopalakrishnan, V., Sekhar,W.Y., Soo.,E.H. Vinsent,R.A., Devi,S. 2002. Typhoid fever in Kuala Lumpur and a comparative evaluation of two commercial diagnostic kits for the detection of antibodies to Salmonella typhi. Singapura Med.

Hatta, M., Goris, M. G. A., Heerkens, E.,Gooskens, J., Smits, HI. 2002. Simple dipstik assay for the detection of $S$. typhi specific IgM antibodies and the evolution of the immune response in patient with typhoid fever. The American Journal of Tropical Medicine and Hygiene, vol. 66 , no.4, hal. 416-421.

Hatta, M., Mubin, H., Abdoel, T., Smits., Henk, L. 2002. Antibody response in typhoid fever in endemik Indonesia and the relevance of serology and culture to diagnosis. Southeast Asian Journal Tropical Medicine and Public Health, vol.33; 182191.

Hatta, M and Smits, H.L., 2007. Detection of Salmonella typhi by Nested Polimerase Chain Reaction in Blood, Urine, and Stool Samples. The American

Journal Tropical Medicine and Hygiene, vol.76 no.1 ; 139-143.

Handojo I, dkk., 2004. Imunoessay terapan pada beberapa penyakit Infeksi. Airlangga University Press, Jakarta.

Handojo I. 2004. Comparasion of the Diagnostic Value of Local Widal slide Test with Imported Widal Slide Test. Southeast Asian J Trop Med Public Health.

Hartini, R. 2000. Perbandingan 3 cara biakan $S$. typhosa, $S$. paratyphosa $A$, dan $S$. paratyphosa $B$ sebagai penunjang diagnosis demam tifoid. NEXUS vol. 13 no.1; 117121.

Hoffman SL. Typhoid Fever.,1991., Dalam : Strickland GT, Ed. Hunter's Textbook of Pediatrics, edisi 7. Philadelphia : WB Saunders.,:344-58.

House, D., Chinh,N.T., Diep, T.S., Parry,C.M. Wain, J., Dougan,g., White,n.J.,Hien,T.T., Farrar,J.J. 2005. Use of paired serum samples for serodiagnosis of typhoid fever. J. Clin. Microbiol.

Jawetz., Melnick., Adelberg. 1995. Mikrobiologi Kedokteran edisi 20. Penerbit Buku Kedokteran EGC. Jakarta.

Jesudason,M., Esther, E., Mathai. Typhidot test to the detect IgM dan IgG antibodies in typhiod fever. Indian J. Med

Juwono R. 2004. Demam Tifoid. Dalam : Buku ajar IImu Penyakit Dalam. Edisi 4. Pusat penerbitan Departemen IImu Penyakit Dalam FK UI. 
Karim, A. 2005. Analysis of Culture, Resistance and Polymerase Chain Reaction Test of Salmonella typhi On Children Suspected To Typhoid Fever In DR. Wahidin Sudirohusodo Hospital In Makassar. Thesis Hasanuddin University, Makassar.

Kresno, SB. 2001. Imunologi: Diagnosis dan Prosedur Laboratorium, Edisi IV. Fakultas Kedokteran Universitas Indonesia. Jakarta.

Kadang, KJ. 2000. Pengenalan Dini Demam Tifoid. Makalah Temu Muka dan Konsultasi Metode Mengatasi Demam Berdarah dan Tifoid. Klinik Anakku Bekasi, Jakarta.

Keusch G.T., 1999. Salmonellosis. Dalam : Prinsip - Prinsip IImu Penyakit Dalam. Harrison. Edisi 13.EGC. Jakarta.

Kwenang, O, A., 2007. Analisis Seologis dan Molekuler pada Populasi Endemik Tifoid untuk Menentukan Tingkat Endemisitas di Jeneponto. Disertasi, UNHAS.

Lay, BW. 1994. Analisis Mikroba di Laboratorium. PT Raja Grafindo Persada Jakarta.

Lakare, Chairuddin. 2001. Catatan Kuliah Mikrobiologi Kedokteran II (Bagian Khusus). Bagian Mikrobiologi Kedokteran Fakultas Kedokteran Universitas Hasanuddin, Makassar.

Manguluang M.2006; Pencegahan dan Pemberantasan Penyakit, Sub Dinas Propinsi Sulawesi Selatan.
Massi M.N., Shirakawa.T., Gotoh A., Bishnu A., Hatta M., Kabawata M., 2003. Rapid diagnosis of thyphoid fever by PCR assay using one pair of primers from flagellin gene of Salmonella typhi. J. Infrct Chemoter.

Miller S.I., Lesser.C.F. 2001.Salmonellosis. Dalam : Principles of Internal Medicine. Harrison's. Edisi $15^{\text {th }}$.

Muliawan, SY., Surjawidjaja, JE. 1999. Tinjauan ulang peranan uji widal sebagai alat diagnostik penyakit demam tifoid di rumah sakit. Cermin Dunia Kedokteran No. $124 ; 82-86$.

Mokoginta, M.N., 2002. Perbandingan Uji Widal slide AIM dengan Widal Tabung sebagai penunjang Diagnosis Demam Tifoid dewasa di Surabaya.Karya Akhir. FKUnair.

Myvrik, Quentin N., Russel S. Weiser, 1998. Fundamental of Medical Bacteriology and Mycology, Lea \& Febiger, Philadelphia.

Muliawan, SY., Surjawidjaja, JE. 1999. Diagnosis Dini Demam Tifoid Dengan Menggunakan Protein Membran Luar S. typhi Sebagai Antigen Spesifik. Cermin Dunia Kedokteran No. 124; 121-126.

Oleson, S.J., et all. 2004. Evaluation of rapid diagnostic test for typhoid fever. J. Clin. Microbiol.

Pang T. 1995. Moleculer biology as a diagnostic tool in Salmonellosis. Dalam : Sarasobath S., Senawong S., Second AsiaPasific symposium of typhoid 
Analisis Metode Serologi Widal Lapangan, Widal Pembanding, Dan Kultur Pada Penderita Suspek Demam Tifoid Di Sulawesi Selatan

fever and other Salmonellosis.

SEAMEO Regional tropical Medicine and public health network. Thailand.

Pelczar, J. 1998. Dasar-dasar Mikrobiologi Jilid II, Universitas Indonesia Press. Jakarta.

Punjabi, N.H. 2004. Beban Penyakit Demam Tifoid Serta Salmonelosis Lainnya Berdasarkan Hasil Surveilan Pasif Di Dua Kecamatan Jakarta Utara Indonesia. Regional Center For Community Nutrition University Indonesia, Jakarta

Purwaningsih S., Handojo I., Prihatini., Probohoesodo Y., 2001. Diagnostic value of dot enzyme immunoassay test to detect outer membrane protein antigen in sera of patients with typhoid fever. Southheast Asian J Trop Med Public Health.

Pollack, D.V., 2003. Salmonella enterica typhi. http://web.uconn.edu/mcbstaff/g raf/student\%20presentations/sal monella typhi.html. Diakses pada tanggal 18 september 2006.

Pawitro UE, Noorvitry M, Darmowandowo W. Demam Tifoid. Dalam : Soegijanto S, Ed.IImu Penyakit Anak : Diagnosa dan Penatalaksanaan, edisi 1. Jakarta : Salemba Medika,2002:1-43.

Prasetyo RV, Ismoedijanto. 2003. Metode Diagnostik Demam Tifoid pada Anak. SMF IImu Kesehatan Anak FK-UNAIR, $p$ ;1-11
Rampengan T.H., Laurentz I.R., 1992. Demam Tifoid. Dalam : Penyakit Infeksi Tropik pada Anak.EGC.Jakarta.

Rani A.A., dkk., 2006. Demam Tifoid. Dalam : Panduan Pelayanan Medik. Perhimpunan Dokter Spesialis Penyakit Dalam. FKUl.Jakarta.

Rasmilah, 2001. Thypus. Fakultas Kesehatan Masyarakat Universitas Sumatera Utara.

Rewa, S. N. 2000. Sistim Imunologi Histologi, Fakultas Kedokteran Universitas Hasanuddin, Makassar

Roitt I. 2003. Imunologi.Edisi 8.Widya Medika.Jakarta.

Santoso, Sanarto. 2003. Protein Adhesin Salmonella typhi Sebagai Faktor Virulensi Berpotensi Imunogenik Pada Produksi S-lga Protektif. Universitas Airlangga, Surabaya.

Sjaifoellah, Moch., 1996. Ilmu Penyakit Dalam, Jilid I, Penerbit FK-UI, Jakarta.

Stephenson T.J., 1999. Imunologi dan Imunopatologi. Dalam :Patologi Umum dan Sistematik.Edisi 2.EGC.Jakarta.

Syahrurachman, dkk., 1994. Buku Ajar Mikrobiologi Kedokteran edisi Revisi. Binarupa Aksara. Jakarta.

Sabir., Yadi., Firdaus., Hatta. 2003. Perbandingan tes serologi dipstik dengan widal untuk diagnosis demam tifoid. Jurnal 
Analisis Metode Serologi Widal Lapangan, Widal Pembanding, Dan Kultur Pada Penderita Suspek Demam Tifoid Di Sulawesi Selatan

Kedokteran Trisakti, vol. 22, no.3, hal. 83-86.

Sacher, Ronald A., Richard A.M., 2004 Tinjauan Klinis Hasil Pemeriksaan laboratorium. Edisi 11, EGC, hal : 3-4

Snowden, K and Hommel, M., 1995. AntigenDetectionlmmunoassay Using Dipstik and Colloidal Dyes. Journal of Immunological Methods. L sevier Sciebce Publishers.

Song J.H., H. Cho, M.Y., Park, D., S.D.Na., H.B. Moon, and C. H. Pai. 1993. Detection of Salmonella typhi in the blood of patients with typhoid fever by PCR. J. Clin. Microbiol.

Taat Putra, S. 1999. Biologi molekuler Kedokteran. Edisis 1. Airlangga University Press. Surabaya.

Tumbelaka AR, Retnosari S., 2001. Imunodiagnosis Demam Tifoid. Dalam : Kumpulan Naskah Pendidikan Kedokteran Berkelanjutan IImu Kesehatan Anak XLIV. Jakarta : :65-73.

Tumbelaka AR, Retnosari S., 2003. Tata Laksana Demam Tifoid. Dalam : Kumpulan Naskah Pendidikan Kedokteran Berkelanjutan IImu Kesehatan Anak XLIV. Jakarta : :65-73.
Wardhani P., Prihatini., M.Y. P. 2005. Kemampuan Uji Tabung Widal Menggunakan Antigen Import dan Antigen Lokal. Indonesian Journal of Clinical Pathology and Medical laboratory, Vol 12 : 31-37

Widodo D.2006. Demam Tifoid. Dalam : Buku Ajar Ilmu Penyakit Dalam. Edisi 4. Pusat Penerbitan IImu Penyakit Dalam FK UI.

Windarti dan Hardjoeno. 1998. Sensifitas Hasil Pemeriksaan Gall Kultur Pada Penderita Demam Tifoid di RSUP Dr. Wahidin Sudirohusodo. Bagian Patologi Klinik Fakultas Kedokteraan. Universitas Hasanuddin, Kumpulan Makalah Pertemuan IImiah Berkala (PIB) X;341-344.

WHO. 2003. The Diagnosis, Treatment And Prevention Of Typhoid Fever.(Online).(http://www.sear o.who.int/LinkFiles/Publications HLM 382Rev1.pdf, diakses 29 November 2007).

Willke A., Ergonul O, Bayar B. 2002. Widal test in diagnosis of typhoid fever in Turkey. Clin Diagn Lab Immunol.

Yuwono T. 2006. Teori dan Aplikasi Polymerase Chain Reaction. Andi .Yogyakarta. 